\title{
FAKTOR-FAKTOR PERILAKU PERUNDUNGAN PADA PELAJAR USIA REMAJA DI JAKARTA
}

\section{Factors of Bullying Behavior of Adolescence Age Students' in Jakarta}

\author{
Wenny Theodore ${ }^{1)}$, Shanty Sudarji ${ }^{2)}$ \\ 1), 2)Program Studi Psikologi Universitas Bunda Mulia
}

\begin{abstract}
Bullying is a widespread problem in Jakarta. Bullying is caused by several factors such as parenting, schooling, self-esteem and group norms. To prevent bullying, students need to be intervened from various parties based on factors that influence the behavior of bullying. This research was conducted to determine the factors that influence students engaging in bullying at school. This research used qualitative method with phenomenological approach. The technique used in data collection is interview and observation. Data analysis techniques included coding, data organization, thematic analysis, interpretation stages and knowing the validity of the data using source triangulation techniques for testing the allegations. The results showed the factors of parenting, schooling, self-esteem and group norms in WA, $J$ and NC. Bullying by AE is caused by factors of parenting, schooling and group norms. Whereas AJ's bullying is caused by factors of parenting and group norms. Based on these results, it is known that parenting, school, self-esteem and group norms can cause students to engage in bullying. Then, there are links between parenting factors, schools and group norms.
\end{abstract}

Keywords: students; bullying; adolescents

\begin{abstract}
ABSTRAK
Perundungan pada pelajar merupakan masalah yang marak terjadi di Jakarta. Perundungan ini disebabkan oleh beberapa faktor seperti pola asuh, sekolah, harga diri dan norma kelompok. Untuk mencegah perilaku perundungan yang terjadi, pelajar perlu diberikan interevensi dari berbagai pihak berdasarkan pada faktor yang mempengaruhi perilaku perundungan. Penelitian ini dilakukan untuk mengetahui faktorfaktor yang berperan mempengaruhi pelajar usia remaja dalam melakukan perilaku perundungan. Penelitian ini menggunakan metode kualitatif dengan pendekatan fenomenologi. Teknik yang digunakan dalam pengambilan data adalah wawancara dan observasi. Teknik analisa data yang digunakan meliputi koding, organisasi data, analisis tematik, tahapan interpretasi dan mengetahui keabsahan data dengan menggunakan teknik triangulasi sumber untuk pengujian terhadap dugaan. Hasil penelitian menunjukkan adanya faktor pola asuh, sekolah, harga diri dan norma kelompok pada WA, J dan NC. Perilaku perundungan yang dilakukan AE disebabkan oleh faktor pola asuh, sekolah dan norma kelompok. Sedangkan perilaku perundungan yang dilakukan AJ disebabkan oleh faktor pola asuh dan norma kelompok. Berdasarkan hasil tersebut, diketahui bahwa faktor pola asuh, sekolah, harga diri dan norma kelompok dapat menyebabkan pelajar melakukan perilaku perundungan. Kemudian, terdapat kaitan antara faktor pola asuh, sekolah dan norma kelompok.
\end{abstract}

Kata kunci: pelajar; perundungan; remaja

\section{PENDAHULUAN}

Perilaku perundungan atau biasanya dikenal dengan bullying, didefinisikan sebagai tindakan negatif dalam bentuk verbal, fisik dan relasional;

*Korespondensi Penulis: wennytheoo@gmail.com ${ }^{1}$, ssudarji@bundamulia.ac.id ${ }^{2}$ terjadi dalam waktu yang cukup panjang dan berulang yang dilakukan oleh satu orang atau lebih terhadap orang lain, dimana terdapat ketindakseimbangan kekuatan dan korban tidak memiliki kemampuan untuk melindungi dirinya (O'Connell, 2003 dalam Lestari, 2016). Perundungan merupakan kasus yang marak terjadi di Indonesia. Kasus perundungan mengalahkan tawuran pelajar, diskriminasi 
pendidikan maupun aduan pungutan liar. Kasus perundungan ini marak terjadi pada kalangan pelajar (Lestari, 2016).

UNICEF pada tahun 2016 merilis bahwa Indonesia menempati peringkat pertama dalam kasus kekerasan pada anak di sekolah, dengan persentase sebesar $84 \%$. Persentase tersebut masih lebih tinggi jika dibandingkan dengan Vietnam dan Nepal dengan persentase yang sama, yaitu 79\% (Weekly, 2017). Sunarto (2017) mengemukakan bahwa Komisi Perlindungan Anak Indonesia (KPAI) mencatat terdapat 1.483 kasus perundungan di seluruh Indonesia dalam periode 20112016, yang melibatkan anak-anak sebagai pelaku. Yayasan SEJIWA (dalam Fitria \& Auli, 2016) melakukan penelitian pada tahun 2008 mengenai kasus perundungan di kalangan pelajar, kemudian mendapati bahwa kasus perundungan paling besar di Indonesia terjadi di kota Yogyakarta, Surabaya dan Jakarta.

Sekolah yang seharusnya memberikan rasa aman dan nyaman kepada anak-anak serta membantu dalam pembentukan karakter siswa/i justru menjadi tempat tumbuhnya perilaku perundungan (Kustanti, 2017). Komisi Perlindungan Anak Indonesia (KPAI) juga mencatat bahwa kasus perundungan di kalangan pelajar pada tahun 2011-2016 paling banyak terjadi di wilayah Jabodetabek dan Bandung dengan 916 kasus (61,7\%) (Sunarto, 2017). Berdasarkan pada data tersebut, diketahui bahwa Jakarta tetap menjadi kota dengan kasus perundungan terbanyak. Pada bulan Agustus 2017, tercatat kasus perundungan sekitar 253 kasus di Jakarta. Jumlah kasus tersebut terdiri dari 122 anak yang menjadi korban dan 131 anak yang menjadi pelaku (Muthmainah, 2017).

Pada umumnya, bentuk perilaku perundungan dapat dilakukan melalui fisik, verbal dan mental atau psikologis. Perilaku perundungan melalui fisik meliputi tindakan menampar, menginjak kaki, meludahi, menghukum, melempar dengan barang, meludahi, dsb. Perilaku perundungan melalui verbal meliputi makian, hinaan, menjuluki, meneriaki, menuduh, menyebarkan gosip, dsb.
Terakhir adalah perilaku perundungan melalui psikologis, yang tidak kasat mata. Perilaku ini menyerang mental atau psikologis korban melalui tindakan verbal atau fisik, namun menyerang psikologis korban (Lestari, 2016).

Kasus perundungan di Jakarta tersebar luas dalam berbagai kalangan usia. Junita, dkk. (2017) dalam penelitiannya menyatakan terjadi perilaku perundungan di sekolah Diponegoro 1, Jakarta Timur. Berdasarkan pada penelitian tersebut, terdapat tiga siswa berinisial R (13), F (14) dan D (12) yang menjadi pelaku perundungan dengan cara memukul, merusak benda orang lain, meminta uang secara paksa, mengucilkan, mengejek nama orang tua, serta menghina dengan kata-kata kasar dan kotor. Yusuf (2017) juga melansir kasus perundungan di SMKN 56, Jakarta Utara. Siswa berinisial RAS (16) yang melakukan perundungan terhadap 5 orang pelajar. Informasi tambahan mengenai kasus perundungan di SMKN 56 menyatakan bahwa terdapat video yang tersebar di sosial media, pelaku menendang punggung korbannya (Pradewo, 2017).

Prastiya (2017) melakukan penelitian mengenai perilaku perundungan yang dilakukan oleh siswa SMP di sekolah Bukit Sion, Jakarta Barat. Berdasarkan pada penelitian tersebut, terdapat siswa berinisial $\mathrm{BF}$ yang merundung siswa/i lain secara verbal dan fisik. BF sering menggunakan kata kotor, merendahkan temannya dengan menonjolkan kelebihannya dalam bermain basket dan mengancam teman. BF melakukan hal tersebut agar diakui oleh temannya. Qodar (2017) melansir terjadinya kasus perundungan di sebuah pusat perbelanjaan daerah Tanah Abang, Jakarta Pusat. Pelaku perundungan adalah beberapa siswa SMP dan SD dengan kisaran umur 12 tahun. Mereka melakukan perundungan terhadap siswi kelas $6 \mathrm{SD}$ (12). Kasus perundungan ini juga tersebar melalui video di media sosial. Korban perundungan sempat ditarik rambutnya, dimaki, dipukuli, serta diminta untuk mencium tangan dan kaki pelaku perundungan (Lazuardi, 2017).

Kasus perundungan lainnya terjadi di sekolah SMAN 3, Jakarta Selatan. Lima 
senior kelas 3 SMA berumur 17 tahun terhadap empat juniornya yang duduk di kelas 1 SMA (15) (Rudi, 2016). Siswi-siswi kelas 3 SMA merundung adik kelasnya dengan memerintahkan mereka untuk menggunakan penahan dada, menghisap rokok, dan menebarkan abu rokok ke atas kepala korban (Lazuardi, 2017).

Berdasarkan pada hasil wawancara langsung dengan pelaku perundungan, $\mathrm{W}$ seorang siswa laki-laki berumur 17 tahun merundung secara fisik dan verbal, yaitu menghina, mencaci maki, memarahi dan memukul seorang siswa laki-laki berinisial $\mathrm{Z}$ di kelasnya. $\mathrm{W}$ merundung sejak umur 14 tahun. W merundung bersama dengan teman-temannya setiap hari saat tidak ada pengawasan guru di sekolah. Perilaku perundungan $\mathrm{W}$ lakukan karena pada awalnya $W$ merasa terganggu dengan perilaku $\mathrm{Z}$ yang sering mendekati, menggoda dan mencari perhatian terhadap W. Perilaku Z membuat siswa/i di kelas menjadi sering mengejek $\mathrm{W}$ dengan berkata bahwa W memiliki hubungan spesial dengan $\mathrm{Z}$. W tidak terima diejek seperti itu, hingga akhirnya $\mathrm{W}$ memaki dan menghina $\mathrm{Z}$ di kelas. Akhirnya perilaku ini terus berlanjut hingga saat ini.

Sekolah W juga masih menganut senioritas, dimana adik kelas harus mengikuti perintah dari kakak kelas seperti membelikan makanan/minuman di kantin, menyuruh adik kelas mendekati seorang perempuan atau merundung siswa/i lainnya. Selalu ada oknum-oknum tertentu yang menjadi pelaku di setiap kelas. Biasanya, sasarannya adalah adik kelas dengan paras kutu buku. W dan beberapa siswa/i lain juga melakukan hal tersebut. W menyatakan bahwa perilakunya saat menyuruh adik kelas melakukan sesuatu hanya terlihat seperti seorang teman yang meminta bantuan kepada temannya yang lain. Namun apabila ada adik kelas yang menolak, maka adik kelas tersebut akan dirundung oleh $\mathrm{W}$ dan teman-temannya.

F seorang laki-laki berumur 15 tahun juga merundung siswa/i lain di kelas dengan menyembunyikan benda milik siswa/i, mengejek dan memaparkan debu dari penghapus papan tulis ke wajah temannya. F merundung sejak umur 12
Vol.12 (2): 67 - 79. Oktober 2019
p-ISSN: 1979-3707
e-ISSN: 2581-0871

tahun. F biasanya merundung bersama dengan teman-temannya setiap $h$ ari saat tidak ada pengawasan guru di sekolah. $\mathrm{F}$ memang sering merundung sejak kecil karena keinginannya sendiri. Pada saat pertama kali merundung, $F$ hanya ingin bergurau dengan mengejek seorang siswa di kelas. Namun, F menjadi ketagihan merundung dengan tujuan untuk bergurau karena menganggap perilaku tersebut asyik untuk dilakukan.

Perilaku perundungan juga dilakukan oleh seorang laki-laki berinisial $\mathrm{C}$ yang berumur 17 tahun. $\mathrm{C}$ merundung secara verbal dan fisik, berupa memukul kepala, menghina dan mengejek siswa/i lainnya di kelas. C merundung sejak berumur 15 tahun. Awalnya, C merundung karena diajak oleh teman-teman dekatnya. C merundung setiap hari bersama dengan teman-temannya saat tidak ada pengawasan guru di sekolah.

L seorang perempuan berumur 16 tahun merundung siswa/i lain secara verbal, yaitu menghina seorang siswi berinisial $\mathrm{Y}$ di kelasnya bersama dengan temantemannya yang lain. L merundung Y karena $\mathrm{Y}$ sering menunjukkan perilaku yang dianggap aneh oleh $\mathrm{L}$ dan siswa/i lain di kelas. Y sering menari-nari sendiri di kelas dan memanggil siswa/i di kelas kemudian tertawa sendiri. Oleh sebab itu, L dan siswa/i lain sering mengejek $\mathrm{Y}$ dengan sebutan "orang aneh", "orang gak jelas", "dasar gila" dan sebagainya. L dan siswa/i lainnya juga sering memarahi dan memusuhi Y. Saat istirahat berlangsung, tidak ada siswa/i yang mau bermain atau mengajak Y berbicara.

O'Connell (2015) menyatakan bahwa perilaku perundungan melakukan kekerasan terhadap temannya berdasarkan pada faktor-faktor tertentu berupa pola asuh orangtua, pengaruh sekolah, pengaruh harga diri, dan norma kelompok. Faktor pola asuh orangtua mencakup penggunaan perilaku perundungan sebagai cara dalam mendidik anak. Akhirnya, anak meniru perilaku perundungan yang diajarkan orangtuanya dan menganggap bahwa perilaku tersebut adalah perilaku yang wajar dan bisa diterima oleh orang lain. Lebih lanjut lagi, Swearer \& Hymel (2015) juga 
mengemukakan bahwa kurangnya perhatian dari keluarga, lingkungan keluarga yang negatif, kurangnya dukungan emosional dari keluarga, didikan secara otoriter, kekerasan yang dilakukan orang tua terhadap anak maupun kurangnya kedisiplinan dapat menjadi faktor anak dalam melakukan perilaku perundungan. Dalam pengaruh individu secara pribadi, didapati bahwa individu yang melakukan perundungan biasanya memiliki kemampuan sosial dan status sosial yang lebih tinggi daripada teman sebayanya.

Berdasarkan pada hasil lapangan yang dilakukan, orangtua $\mathrm{W}$ dan $\mathrm{F}$ tidak menggunakan perilaku perundungan sebagai cara dalam mendidik anak. Sedangkan, orangtua $\mathrm{C}$ menggunakan perilaku perundungan secara verbal dan fisik yaitu merundung, memaki dan memarahi $\mathrm{C}$ ketika ayahnya pulang dari rumah dalam kondisi mabuk. Selain itu, orangtua $\mathrm{C}$ juga tidak mau ikut campur dan bersikap tak acuh dengan kegiatan seharihari yang $\mathrm{C}$ lakukan. Lain lagi dengan $\mathrm{L}$, orangtua $\mathrm{L}$ mengetahui perilaku perundungan yang L lakukan di sekolah dan menganggap bahwa perilaku perundungan yang L lakukan adalah hal yang wajar.

Kedua, faktor sekolah yaitu apabila guru dan pihak sekolah menunjukkan sikap tak acuh terhadap perilaku kekerasan yang dilakukan antar siswa/i, maka hal tersebut dapat memicu siswa/i melakukan perilaku perundungan di sekolah (O'Connell, 2003). Swearer \& Hymel (2015) mengemukakan apabila lingkungan sekolah negatif, maka frekuensi perundungan dapat lebih tinggi. Respon guru juga berpengaruh pada kasus ini. Apabila guru tidak memberi dukungan positif terhadap murid dan kurang mengikuti aktivitas sekolah, maka kemungkinan terjadinya perilaku perundungan akan semakin meningkat. Douglas (dalam Rahmawati, 2016) menyatakan bahwa frekuensi terjadinya perundungan dan bentuk agresi lainnya merupakan masalah terbesar yang dihadapi sekolah.

Berdasarkan pada hasil wawancara yang dilakukan, ditemukan adanya faktor sekolah yang membuat individu di sekolah melakukan perilaku perundungan. Guru W,
$\mathrm{C}$ dan $\mathrm{F}$ tidak mengetahui perilaku perundungan yang $\mathrm{W}, \mathrm{C}$ dan $\mathrm{F}$ lakukan di sekolah, karena $\mathrm{W}, \mathrm{C}$ dan $\mathrm{F}$ cenderung merundung saat tidak ada pengawasan guru. Oleh sebab itu, W, C dan F tetap merundung karena belum pernah mendapat teguran dari guru. Sedangkan guru L melakukan mediasi dengan memberikan nasihat dan edukasi mengenai perilaku perundungan. Namun L dan temantemannya masih merundung karena merasa Y memang pantas untuk dirundung.

Ketiga, faktor harga diri meliputi individu memiliki rasa harga diri negatif atau rendah, sehingga ia memandang dirinya tidak berharga. Individu memiliki kesulitan dalam menjalin hubungan dengan temannya, sehingga individu mudah tersinggung dan marah. Akibatnya, individu cenderung melakukan perbuatan berupa merundung atau menyakiti temannya. Pada faktor harga diri, W merundung karena siswa/i yang merundung di sekolah akan terlihat hebat, disegani dan lebih dikenal oleh siswa/i lain. L merundung karena seluruh siswa/i lain juga merundung Y. L jadi merasa memiliki derajat yang sama seperti siswa/i lain yang memiliki sikap dan sifat yang normal. L juga menjadi memiliki pandangan bahwa dirinya lebih berharga daripada Y. Sedangkan, W dan F tidak menunjukkan adanya faktor perundungan yang mereka lakukan karena $\mathrm{W}$ dan $\mathrm{F}$ merundung hanya untuk kesenangan pribadi.

Pada faktor norma kelompok, teman dekat $\mathrm{W}$ juga merundung siswa/i lain dan sering memprovokasi $\mathrm{W}$ untuk merundung. Akhirnya, W juga ikut merundung. Pada faktor norma kelompok, awalnya $F$ yang mengajak teman-temannya untuk merundung siswa/i lain. F mengajak mereka pada saat kali kedua $F$ ingin merundung siswa/i lain. Teman-teman $F$ menunjukkan respon posiitf dan mendukung $F$ untuk merundung, dengan mengikuti perilaku perundungan yang $\mathrm{F}$ lakukan dan sekarang teman-teman $F$ juga sering mengajak $F$ untuk merundung siswa/i lain di kelas.

Pada faktor norma kelompok, temanteman dekat $\mathrm{C}$ di sekolah juga merundung. Perilaku perundungan merupakan hal yang sangat wajar dilakukan bagi teman-teman 
dekat C. Hal ini juga membuat $\mathrm{C}$ merasa perilaku perundungan yang ia lakukan adalah wajar untuk dilakukan. Pada faktor harga diri, L sebenarnya merundung karena Pada faktor norma kelompok, seluruh siswa/i mewajarkan perilaku perundungan terhadap Y karena Y memang terkenal memiliki sifat dan sikap yang aneh, sehingga siswa/i di kelas L tidak merasa bersalah atas perilaku yang mereka lakukan, begitu juga dengan L. Pada faktor norma kelompok terhadap perilaku perundungan terjadi apabila perilaku perundungan dianggap sebagai perilaku yang wajar dan dapat diterima dalam kelompok tersebut. Biasanya, individu yang ingin bergabung dalam kelompok tersebut akan diajarkan norma/aturan yang berlaku dalam kelompok tersebut, termasuk perilaku perundungan. Setiap anggota kelompok juga saling memberikan dukungan satu sama lain untuk melakukan perundungan.

Hal yang perlu diperhatikan pada kasus-kasus tersebut adalah kasus perundungan di kalangan pelajar banyak terjadi pada usia remaja. Menurut Papalia, dkk. (2012), remaja merupakan individu yang berada pada jenjang usia 11-19 tahun. Pada masa remaja, mereka akan mengalami krisis identitas, dimana remaja sedang mencari konsep diri, membuat tujuan, mencari nilai diri dan memberi kepercayaan kepada orang yang dapat ia percaya. Pada tahap ini, identitas diri remaja dipengaruhi oleh tipe pengasuhan orang tua, teman, lingkungan sosial dan budaya (Papalia, dkk., 2012). Setelah ditelusuri lebih lanjut, adanya kemiripan antara faktor yang mempengaruhi identitas diri remaja juga menjadi faktor remaja dalam melakukan perilaku perundungan. Berdasarkan pada kemiripan faktor yang mempengaruhi terbentuknya identitas diri remaja dan perilaku perundungan, dikhawatirkan bahwa perilaku perundungan juga dapat memberikan dampak buruk pada perkembangan identitas remaja.

Einsberg (dalam Surilena, 2016) menyatakan bahwa $57 \%$ orang yang pernah mengalami kasus perundungan di usia kanak-kanak, saat mereka dewasa akan mengalami depresi, mempunyai kepercayaan diri rendah dan masalah interpersonal. Tentunya, perilaku perundungan ini akan terus bertambah apabila adanya pelaku yang melakukan perundungan terhadap individu lain (Surilena, 2016). Apabila perilaku perundungan terus berlanjut, maka hal ini dapat mengakibatkan dampak buruk pada korban secara fisik, mental maupun psikologis (UNESCO, 2017).

Korban perundungan biasanya memiliki karakteristik tertentu terkait dengan adanya disabilitas, perbedaan jenis kelamin, status sosial, perbedaan etnis, kultur atau linguistik, penampilan fisik dan orientasi seksual (UNESCO, 2017). Disadari atau tidak, perilaku perundungan terhadap anak dan remaja dapat mengakibatkan berbagai dampak yaitu kesepian, pencapaian akademi yang buruk, sulit beradaptasi, meningkatnya resiko keterlibatan dalam tindakan kriminal, serta rentan terhadap gangguan mental emosional (cemas, insomnia, dan depresi) (Surilena, 2016).

Selain itu, perilaku perundungan juga mengakibatkan dampak buruk pada pelaku perundungan. Lund (dalam Surilena, 2016) juga menyatakan bahwa individu yang menjadi pelaku perundungan saat berusia 8 tahun memiliki resiko 3 kali lebih besar mengalami depresi saat berusia 18 tahun dibandingkan dengan yang tidak terlibat kasus perundungan. McKenna, dkk. (dalam Surilena, 2016) juga menyatakan bahwa pelaku perundungan memiliki resiko tiga kali lebih besar dan korban memiliki resiko lima kali lebih besar dalam mengalami gangguan mental emosional 10-15 tahun kemudian. Oleh sebab itu, faktor-faktor pelaku dalam melakukan perilaku perundungan perlu diperhatikan dengan tujuan untuk mengetahui langkah-langkah yang perlu dilakukan dalam melakukan pencegahan terhadap kasus perundungan (UNESCO, 2017).

Dengan adanya faktor-faktor tersebut, maka dapat memungkinkan perilaku perundungan terus terjadi. Perilaku perundungan tersebut memberikan dampak buruk baik pada pelaku maupun korban perundungan. Berdasarkan pada latar belakang tersebut, peneliti ingin melakukan penelitian "Faktor-Faktor Penyebab 
Perilaku Perundungan Pada Pelajar Usia Remaja di Jakarta."

\section{METODE PENELITIAN}

\section{Rancangan Penelitian}

Metode yang digunakan dalam penelitian ini adalah metode kualitatif, dengan tipe fenomenologi. Penelitian kualitatif adalah pendekatan yang memahami manusia dengan mempelajari isu-isu secara mendalam dan mendetail, serta mengolah data yang bersifat deskriptif seperti transkrip wawancara, catatan lapangan, foto dan sebagainya (Poerwandari, 2011). Pendekatan fenomenologi diartikan sebagai pengalaman subjektif dan kesadaran perspektif seseorang, yang menekankan kedalaman pengalaman subjek dari berbagai jenis dan tipe subjek yang ditemui (Moleong, 2010).

\section{Subjek Penelitian}

Karakteristik subjek dalam penelitian ini adalah pelajar usia remaja (berumur 1118 tahun) yang melakukan perilaku perundungan dan bersekolah di Jakarta. Subjek melakukan perundungan secara berulang terhadap korban serta telah merundung lebih dari satu tahun. Peneliti mengambil masing-masing satu subjek yang bersekolah di Jakarta Utara, Jakarta Timur, Jakarta Barat, Jakarta Pusat dan Jakarta Barat. Sampel dalam penelitian ini berjumlah 5 orang yang memenuhi karakteristik yang telah ditentukan.

\section{Variabel dan Definisi Operasional}

Variabel merupakan karakteristik atau atribut individu atau suatu organisasi yang dapat diukur atau diobservasi (Creswell, 2010). Variabel penelitian yang digunakan adalah faktor perilaku perundungan.

Definisi operasional merupakan definisi operasi dari sebuah variabel yang digunakan peneliti untuk mengukur varibael tersebut (Jackson, 2012). Definisi operasional perilaku perundungan adalah perilaku agresif yang dilakukan secara sengaja dan sadar oleh sekelompok pelaku yang lebih kuat erhadap kelompok lain yang lebih lemah, dilakukan dalam bentuk verbal, fisik, psikologis, seksual dan relasional; yang terjadi dalam waktu yang cukup panjang dan berulang.

\section{Teknik Pengambilan Sampel}

Kategori teknik pengambilan sampel dalam penelitian ini adalah non probability sampling, dimana populasi penelitian tidak diketahui, sehingga tidak dapat menarik kesimpulan yang berlaku terhadap populasi secara umum (Gulo, 2010). Pemilihan unit sampling didasarkan pada pertimbangan atau penilaian subjektif dan tidak pada penggunaan teori probabilitas (Siregar, 2013). Sedangkan teknik pengambilan subjek yang digunakan adalah purposive sampling, yaitu penentuan sampel berdasarkan tujuan tertentu dengan syaratsyarat yang harus dipenuhi (Arikunto, 2010)

\section{Metode Pengumpulan Data}

Teknik pengumpulan data dalam penelitian ini menggunakan observasi dan wawancara. Istilah observasi diarahkan pada kegiatan memperhatikan secara akurat, mencatat fenomena yang muncul, dan mempertimbangkan hubungan antar aspek dalam fenomena tersebut. Sedangkan wawancara adalah percakapan dan tanya jawab yang diarahkan untuk mencapai tujuan tertentu (Poerwandari, 2011).

Pendekatan yang digunakan dalam memperoleh data kualitatif melalui wawancara adalah wawancara dengan pedoman umum, yaitu dalam proses wawancara, peneliti dilengkapi dengan pedoman wawancara yang mencantumkan isu-isu tanpa menentukan urutan pertanyaan bahkan mungkin tanpa bentuk pertanyaan eksplisit.

\section{Teknik Analisa Data}

Sebelum melakukan analisa data, maka harus dilakukan pemadatan faktual dan penetuan tema dengan membaca transkrip yang telah dibuat untuk mengidentifikasi kemungkinan tema yang muncul dan menghindari kesulitan dalam mencari tema; selalu membawa buku catatan atau perekam untuk mencatat pemikiran-pemikiran analitis yang secara 
spontan muncul; membaca kembali data dan catatan analisis, dan menuliskan tambahan-tambahan pemikiran, dan pertanyaan yang muncul secara spontan (Poerwandari, 2011). Kemudian, harus dilakukan koding terlebih dahulu yang bertujuan untuk memperoleh gambaran tentang topik yang dipelajari, dengan mengorganisasi dan mensistemasi data secara lengkap dan mendetail (Poerwandari, 2011).

Teknik analisa data dalam penelitian ini menggunakan teknik analisa tematik, yaitu proses mengkode informasi yang dapat menghasilkan daftar tema, model tema atau indikator yang kompleks, kualifikasi yang biasanya terkait dengan tema tersebut. Tema yang ditentukan minimal dapat mendeskripsikan fenomena dan secara maksimal memungkinkan interpretasi fenomena (Poerwandari, 2011).

\section{Kredibilitas Penelitian}

Penelitian ini menggunakan triangulasi teknik dan triangulasi sumber untuk memperoleh keabsahan data. Marshall \& Rossman (dalam Poerwandari, 2011) dan Sugiyono (2012), menjelaskan bahwa triangulasi teknik adalah teknik pengumpulan data yang berbeda-beda untuk memperoleh data dari sumber yang sama. Sedangkan triangulasi sumber adalah memperoleh data dari sumber yang berbeda-beda. Triangulasi digunakan untuk memperoleh kejelasan informasi yang diperoleh. Data yang berbeda dari berbagai sumber digunakan untuk mengelaborasi dan memperkaya penelitian, serta menguatkan derajat manfaat studi pada setting-setting yang berbeda pula.

\section{Prosedur Penelitian}

Peneliti melakukan tahapan persiapan sebelum melaksanakan penelitian. Rangkaian tahapan persiapan dijabarkan dalam bentuk tabel.

Tabel 1. Tahapan Pelaksanaan Penelitian

\begin{tabular}{lll}
\hline No. & Tanggal & Kegiatan \\
\hline 1. & $\begin{array}{l}\text { 9 September } \\
2017\end{array}$ & $\begin{array}{l}\text { Mencari fenomena } \\
\text { dan diskusi judul } \\
\text { penelitian }\end{array}$ \\
\hline 2. & 12 & Mengubah fenomena \\
\hline
\end{tabular}

Vol.12 (2): 67 - 79. OKI $1979-3707$
e-ISSN: 1 -ISSN: 2581-0871

\begin{tabular}{lll}
\hline & $\begin{array}{l}\text { September } \\
2017\end{array}$ & dan judul penelitian \\
\hline 3. & 12 & Membuat surat untuk \\
& September \\
2017 & mencari subjek \\
\hline 5. & $\begin{array}{l}\text { 9 Desember } \\
2017\end{array}$ & $\begin{array}{l}\text { Menghubungi } \\
\text { sekolah J \& AE untuk } \\
\text { melakukan penelitian }\end{array}$ \\
\hline 6. & 8 Januari & $\begin{array}{l}\text { Menghubungi } \\
\text { sekolah NC \& AJ } \\
\text { untuk melakukan } \\
\text { penelitian }\end{array}$ \\
& 2018 & $\begin{array}{l}\text { Menghubungi } \\
\text { sekolah WA untuk } \\
\text { melakukan penelitian }\end{array}$ \\
\hline 7. & 1 Maret 2018 \\
& & \\
\hline
\end{tabular}

\section{HASIL DAN PEMBAHASAN}

\section{Analisa Inter Subjek}

Perilaku perundungan yang

dilakukan WA dipengaruhi oleh berbagai faktor sebagai berikut. Pertama, faktor pola asuh yaitu ketidakhadiran orangtua dan kurangnya bimbingan \& edukasi dari orangtua mengenai perilaku perundugan. Kedua, faktor sekolah yaitu subjektivitas guru yang hanya memerhatikan perilaku negatif yang dilakukan oleh siswa/i dengan nilai yang kurang baik. Sekolah WA juga belum pernah memberikan penyuluhan mengenai perilaku perundungan. Di sekolah WA yang lama, terdapat tradisi yaitu siswa/i SMP yang sering meminta uang kepada siswa/i SD secara paksa. Ketiga, faktor harga diri yaitu ingin meningkatkan rasa percaya diri, ingin lebih dihargai dan disegani setelah merundung siswa/i lain. Keempat, faktor norma kelompok yaitu teman dekat WA yang secara mayoritas juga sering merundung siswa/i lain.

Perilaku perundungan yang dilakukan $\mathbf{J}$ dipengaruhi oleh berbagai faktor berikut. Pertama, faktor pola asuh yaitu orangtua yang banyak memberikan larangan terhadap $\mathrm{J}$ ketika mengetahui dirinya melakukan perilaku negatif, namun tidak memberikan edukasi mengenai perilaku perundungan. Hal ini membuat $\mathbf{J}$ menyimpan perilaku negatif yang ia lakukan di sekolah. Kedua, faktor sekolah yaitu peraturan bahwa siswa/i yang ketahuan merundung akan dikeluarkan dari sekolah. Namun ternyata, J dan temantemannya mencari kesempatan untuk 
merundung saat tidak ada guru di sekitar. Ketiga, faktor harga diri yaitu $\mathbf{J}$ tidak suka apabila temannya menganggap dirinya sebagai penakut. Keempat, faktor norma kelompok yaitu sejak SD, J selalu memiliki teman dekat yang melakukan perilaku perundungan.

Perilaku perundungan yang dilakukan AE dipengaruhi oleh berbagai faktor berikut. Pertama, faktor pola asuh yaitu orangtua $\mathrm{AE}$ yang beranggapan bahwa perilaku perundungan yang $\mathrm{AE}$ lakukan di sekolah dapat ditoleransi dan bukan masalah besar. Kedua, faktor sekolah yaitu sekolah AE belum pernah memberikan penyuluhan mengenai perilaku perundungan. Belum ada peraturan yang ketat sehingga $\mathrm{AE}$ malah semakin berani untuk merundung siswa/i saat ada guru di kelas. Ketiga faktor harga diri tidak mempengaruhi perilaku perundungan yang dilakukan AE. Keempat, faktor norma kelompok yaitu sejak 3 SMP, teman sekelas AE memang sudah terbiasa mengejek satu sama lain menggunakan nama orang tua. Saat SMA, AE kembali bertemu teman dekat yang juga merundung siswa/i lain.

Perilaku perundungan yang

dilakukan NC dipengaruhi oleh faktor berikut. Pertama, faktor pola asuh yaitu ayah NC yang sering memaki dan memukul NC. Hal ini ditiru oleh NC, sehingga ia juga memaki siswa/i di sekolah. Kedua, faktor sekolah yaitu belum ada penyuluhan perilaku perundungan. Guru NC mengecap NC sebagai anak yang nakal. Kemudian juga terdapat guru NC yang memberi sebutan "hitam" namun hanya dalam konteks bergurau. Ketiga, faktor harga diri yaitu NC ingin lebih dihargai, memiliki kekuatan, ingin siswa/i menjadi segan dan takut terhadap dirinya. Keempat, faktor norma kelompok yaitu teman-teman dekat $\mathrm{NC}$ yang sering memanas-manasi NC untuk merundung dan ikut melakukan perilaku perundungan bersama NC.

Perilaku perundungan yang dilakukan AJ dipengaruhi oleh faktor berikut. Pertama, tidak ditemukan adanya kaitan perilaku perundungan dengan pola asuh. Kedua, faktor sekolah yaitu peraturan sekolah bahwa siswa/i yang merundung
Vol.12 (2): 67 - 79. Oktober 2019
p-ISSN: 1979-3707
e-ISSN: 2581-0871

akan dikeluarkan dari sekolah membuat AJ tidak berani merundung di sekolah. tetapi, AJ mencari korban perundungan di tempat lain, yaitu di gereja tempat AJ beribadah. Ketiga, tidak ditemukan adanya kaitan perilaku perundungan dengan faktor harga diri. Perilaku perundungan yang ia lakukan hanya untuk memenuhi kesenangan pribadi. Keempat, faktor norma kelompok yaitu teman dekat AJ di gereja dan di sekolah melakukan perilaku perundungan. AJ tergoda untuk merundung orang lain karena mendengar cerita perilaku perundungan dari kakak dan teman-teman kakak AJ. Tetapi AJ sering dinasihati oleh kakak-kakak AJ di gereja untuk berhenti merundung.

\section{Pembahasan}

Perundungan merupakan perilaku agresif yang dilakukan secara sengaja dan sadar oleh sekelompok pelaku yang lebih kuat terhadap kelompok lain yang lebih lemah, dilakukan dalam bentuk verbal, fisik, psikologis, seksual dan relasional; yang terjadi dalam waktu yang cukup panjang dan berulang (Sullivan, 2003; Olweus, $2003 \&$ Heath \& Sheen, 2005).

Berdasarkan pada hasil wawancara yang dilakukan, orangtua maupun nenek WA tidak menunjukkan perilaku perundungan dalam pola asuh di rumahnya. Namun, WA mengalami kurangnya dampingan dari orangtua serta kurangnya edukasi dari orangtua maupun nenek dan kakek WA mengenai perilaku perundungan. Swearer \& Hymel (2015) juga mengemukakan bahwa kurangnya perhatian dari keluarga dapat menjadi faktor anak dalam melakukan perilaku perundungan. Pada faktor sekolah, guru mengacuhkan perilaku yang dilakukan oleh murid dengan nilai akademis yang cukup baik. Di samping itu, sekolah WA juga belum pernah memberikan penyuluhan mengenai perilaku perundungan. Dodge, Dishion \& Landfar (dalam Papalia, 2016) menyatakan bahwa seharusnya sekolah juga merupakan suatu wadah yang berperan dalam mengintervensi terjadinya kenakalan remaja. Namun di sekolah WA, belum dilakukannya intervensi yang efektif dalam mengatasi perilaku perundungan di sekolah. 
Pada faktor harga diri, WA menunjukkan adanya rasa percaya diri, ingin dihargai dan disegani setelah merundung orang lain. Pada faktor norma kelompok, teman dekat WA memang sering merundung siswa/i lain. Terdapat kaitan antara faktor perilaku perundungan pada subjek WA. Awalnya, faktor pola asuh WA yang kurang baik ditunjukkan dengan kurangnya kehadiran orangtua WA untuk mengasuh WA. Hal ini menyebabkan faktor harga diri WA menurun karena WA dirundung oleh temannya di sekolah sehingga WA merasa tidak percaya diri. Akhirnya, WA masuk ke dalam kelompok dengan norma kelompok yang mewajarkan dilakukannya perilaku perundungan terhadap siswa/i lain di sekolah, sehingga WA merundung hingga saat ini.

Perilaku perundungan yang dilakukan oleh $\mathbf{J}$ dipengaruhi oleh beberapa faktor berikut. Pada faktor pola asuh, orangtua $\mathrm{J}$ tidak menerapkan perilaku perundungan dalam mendidik anak. Orangtua $\mathbf{J}$ bahkan melarang $\mathrm{J}$ untuk merundung. Namun, orangtua $\mathrm{J}$ tidak memberikan edukasi mengenai dampak dari perilaku perundungan, sehingga $J$ berusaha untuk merundung tanpa diketahui oleh orangtuanya. Baumrind (dalam Papalia, 2012) menjelaskan bahwa pola asuh orangtua yang efektif adalah orangtua yang memberikan peraturan dan norma yang penting, namun mau mendengarkan, menjelaskan dan bernegosiasi dengan anak. Orangtua akan mengontrol perilaku anak, namun tidak terlalu mengontrol perasaan dan keyakinan anak. Orangtua $\mathbf{J}$ tampak mengontrol perilaku $J$, namun tidak bernegosiasi atau mendengarkan penjelasan dari J dalam melakukan perilaku perundungan.

Pada faktor sekolah, sekolah $\mathrm{J}$ memberikan peraturan ketat akan mengeluarkan siswa/i yang melakukan perilaku perundungan. Namun, hal ini membuat $\mathbf{J}$ dan teman-temannya berusaha merundung secara diam-diam dan tidak diketahui oleh guru. Menurut Setiawati (dalam Lestari, 2016), perilaku perundungan dapat terjadi di sekolah apabila pengawasan dan bimbingan etika dari guru rendah dan kedisiplinan sekolah kaku. Sekolah J menunjukkan adanya pengawasan dan bimbingan etika dari guru yang rendah. Sekolah J memberikan peraturan mengenai perilaku perundungan, namun tidak memberikan penyuluhan mengenai perilaku perundungan. Pada faktor harga diri, J tidak suka apabila diaanggap sebagai seorang penakut. Oleh karena itu, J merundung siswa/i lain untuk menunjukkan bahwa dirinya bukan seorang penakut.

Pada faktor norma kelompok, J memang selalu memiliki teman dekat yang melakukan perilaku perundungan. Terdapat kaitan antara faktor perilaku perundungan pada subjek J. Awalnya, faktor harga diri berperan dimana $\mathbf{J}$ merasa tidak percaya diri dan lemah ketika ia sedang tidak bersama teman-temannya. Sedangan norma kelompok berperan dalam perilaku perundungan yang $\mathbf{J}$ lakukan karena sejak kecil J memang lebih suka berteman dengan siswa/i yang sering merundung. Hal ini mendorong $\mathrm{J}$ untuk merundung. Setelah merundung, ternyata guru J melaporkan hal tersebut kepada ibu J. Ibu J sempat melarang-larang $\mathrm{J}$ untuk berteman dengan siswa/i yang dianggap memberikan pengaruh buruk. Namun akhirnya, sekarang J menutupi perilaku buruk yang ia lakukan termasuk perilaku perundungan dari ibunya. Hal ini menyebabkan faktor pola asuh juga berperan dalam perilaku perundungan yang J lakukan.

Berdasarkan hasil wawancara dengan AE, Faktor norma kelompok dan pola asuh berperan pada diri AE. Orangtua AE tidak menerapkan perilaku perundungan dalam mendidik anak. Namun, orangtua AE bersikap acuh terhadap perilaku perundungan yang dilakukan $\mathrm{AE}$ di sekolah. Astuti (2008) menyatakan bahwa tidak adanya dukungan dan pengarahan terhadap remaja, membuat remaja memiliki kesempatan untuk menjadi pelaku perundungan (Astuti, 2008). Lebih lanjut lagi, Swearer \& Hymel (2015) juga mengemukakan bahwa lingkungan keluarga yang negatif dapat menjadi faktor anak dalam melakukan perilaku perundungan. Orangtua AE sering menggunakan kata seperti pea dan bego dalam berkomunikasi dengan konteks bergurau. Hal ini 
menunjukkan adanya perilaku negatif yang ditunjukkan orangtua terhadap AE.

Pada faktor sekolah, guru AE menunjukkan perilaku perundungan dengan memberikan julukan pantun terhadap salah satu teman AE. Di samping itu, pihak sekolah belum pernah memberikan penyuluhan mengenai perilaku perundungan. Dishion \& Landfar (dalam Papalia, 2016) menyatakan bahwa seharusnya sekolah juga merupakan suatu wadah yang berperan dalam mengintervensi terjadinya kenakalan remaja. Selama ini, $\mathrm{AE}$ telah ditegur oleh guru BK. Namun, intervensi tersebut belum efektif karena $\mathrm{AE}$ masih merundung hingga saat ini. Faktor harga diri tidak mempengaruhi $\mathrm{AE}$ dalam melakukan perundungan.

Pada faktor norma kelompok, AE terbiasa mengejek satu sama lain menggunakan nama orang tua. Sehingga $\mathrm{AE}$ menganggap bahwa perilaku perundungan yang dilakukannya merupakan hal yang wajar. Terdapat kaitan antara faktor perilaku perundungan pada subjek AE. Awalnya, faktor norma kelompok dan pola asuh berperan pada AE. Teman-teman AE merundung menggunakan nama orangtua dan ternyata orangtua AE juga tidak mempermasalahkan perilaku AE tersebut. Akhirnya, AE pun merasa bahwa merundung adalah hal yang wajar dilakukan.

Perilaku perundungan yang dilakukan NC dipengaruhi oleh beberapa faktor berikut. Faktor pola asuh yaitu ayah $\mathrm{NC}$ yang sering memaki dan memukul NC. Hal ini ditiru oleh NC, sehingga ia juga memaki siswa/i di sekolah. Pada faktor sekolah, guru NC menunjukkan perilaku perundungan dengan memberi sebutan "hitam" namun hanya dalam konteks bergurau. Namun, sekolah belum pernah melakukan penyuluhan perilaku perundungan. Guru NC juga mengecap NC sebagai anak yang nakal. NC mengakui terbiasa dengan sebutan tersebut dan mengakui dirinya nakal karena memang sering melakukan hal negatif. Eccles (dalam Papalia, 2012) peran guru dalam memberikan kepercayaan, sikap menghargai, peduli terhadap pelajar dan memiliki ekspektasi yang tinggi terhadap pelajar sangat mendukung pelajar dalam mencapai kesuksesan. Berdasarkan pada teori tersebut, seharusnya guru $\mathrm{NC}$ mendorong NC untuk menunjukkan perilaku yang baik di sekolah. Kata nakal yang diberikan guru NC terhadap NC membuat NC tidak terdorong untuk mengubah perilakunya menjadi lebih baik.

Pada faktor harga diri, NC ingin lebih dihargai, memiliki kekuatan, ingin siswa/i menjadi segan dan takut terhadap dirinya atas perilaku perundungan yang ia lakukan. Pada faktor norma kelompok, awalnya NC yang memulai untuk melakukan perilaku perundungan. Teman-teman NC hanya mengikuti perilaku perundungan yang $\mathrm{NC}$ lakukan. Sekarang, teman-teman dekat NC sering memanas-manasi NC untuk merundung dan ikut melakukan perilaku perundungan bersama NC.

Terdapat kaitan antara faktor perilaku perundungan pada subjek NC. Awalnya, faktor pola asuh berperan pada diri NC. NC meniru perilaku perundungan yang ayah NC lakukan terhadap NC di rumah. Saat $\mathrm{NC}$ merundung, ternyata $\mathrm{NC}$ mendapat respon positif dari teman dekat $\mathrm{NC}$, hingga akhirnya teman $\mathrm{NC}$ juga sering memprovokasi NC untuk merundung. Hal ini membuat faktor harga diri $\mathrm{NC}$ meningkat. Sehingga NC merundung untuk meningkatkan rasa percaya diri, ingin dianggap hebat dan disegani oleh siswa/i lain di sekolah.

Pada perilaku perundungan yang dilakukan AJ di sekolah, tidak ditunjukkan adanya kaitan antara faktor pola asuh dan faktor harga diri dengan perilaku perundungan yang dilakukan AJ. Pada faktor pola asuh, orang tua $\mathrm{AJ}$ memberikan bimbingan mengenai perilaku perundungan dan alasan perilaku perundungan tidak boleh dilakukan. Pada faktor harga diri, AJ merundung untuk kesenangan pribadi, sehingga tidak berkaitan dengan harga diri AJ. Pada faktor sekolah, AJ tidak berani merundung karena adanya peraturan ketat di sekolah yaitu mengeluarkan siswa/i yang melakukan perilaku perundungan. AJ sempat ditegur oleh gurunya dan diancam dapat dikeluarkan dari sekolah. Hal tersebut membuat AJ jera dan ia mencari korban di tempat lain, yaitu di gereja. Pada faktor 
norma kelompok, teman-teman gereja AJ mengikuti perilaku perundungan yang AJ lakukan. Di samping itu, ada kakak-kakak gereja yang dekat dengan AJ dan sering menasihati AJ untuk tidak merundung. Namun, saat AJ berusaha untuk tidak merundung, teman AJ menghasut dirinya sehingga AJ tetap merundung.

Pada faktor sekolah, guru $\mathrm{NC}$ dan $\mathrm{AE}$ sering kali mengejek siswa di kelas dalam konteks bergurau. Seharusnya, hal ini dihindari karena guru juga memiliki peran untuk mencegah perilaku perundungan di sekolah. Guru di sekolah WA, NC, dan J cenderung kurang memberikan perhatian terhadap perilaku perundungan yang dilakukan siswa/i di sekolah. Sedangkan di sekolah AE, mediasi yang dilakukan guru $\mathrm{AE}$ dengan menasihati $\mathrm{AE}$ untuk merundung kurang efektif karena hingga saat ini AE masih merundung. Dodge, Dishion \& Landfar (dalam Papalia, 2016) menyatakan bahwa seharusnya sekolah juga merupakan suatu wadah yang berperan dalam mengintervensi terjadinya kenakalan remaja.

Pada faktor harga diri, didapati bahwa subjek NC dan WA merundung karena ingin lebih dihargai, tampak lebih hebat dan disegani oleh temannya. Elkind (dalam King, 2013) remaja bersifat egosentris, yaitu kepercayaan bahwa dirinya unik, dan kebal. Egosentrisme remaja ditunjukkan dengan adanya perasaan remaja bahwa orang lain menyadari dan memperhatikan mereka dari pada yang sebenarnya. Kemudian hal ini yang membawa remaja yakin bahwa nilai-nilai yang dimilikinya merupakan hal yang benar.

Pada faktor norma kelompok, didapati bahwa seluruh subjek seringkali dihasut oleh temannya untuk merundung. Kemudian, AJ juga masih merundung bersama dengan teman-teman dekatnya meskipun sudah ditegur dan diberi pengertian oleh orangtua $\mathrm{AJ}$ mengenai dampak buruk dari perilaku perundungan. Hal ini menunjukkan bahwa AJ yang berada pada tahap usia remaja cenderung lebih mengikuti dan mendengarkan temannya meskipun sudah dinasihati oleh orangtua. Erickson (dalam Papalia, 2012) menyatakan bahwa pada masa remaja, individu akan lebih intens dan mementingkan hubungan pertemanan. Masa remaja juga merupakan masa dimana remaja akan menghabiskan banyak waktunya bersama dengan teman jika dibandingkan dengan jenjang/tahap usia lainnya. Remaja juga cenderung meningkatkan intimasi dalam hubungan pertemanan dengan saling berbagi dan menekspresikan pikiran dan perasaan yang bersifat pribadi.

\section{SIMPULAN}

Perilaku perundungan biasanya dilakukan secara verbal dan fisik. Perilaku perundungan secara verbal berupa ejekan dan sorakan sedangkan perilaku perundungan secara fisik berupa mendorong, memukul kepala dan menempelkan cairan di kepala teman. Terdapat beberapa faktor yang dapat menyebabkan pelajar usia remaja melakukan perilaku perundungan, yaitu faktor pola asuh, faktor sekolah, faktor harga diri dan faktor norma kelompok. Berdasarkan pada hasil analisa, ditemukan adanya kaitan antara faktor pola asuh, faktor sekolah, faktor harga diri dan faktor norma kelompok pada perilaku perundungan yang dilakukan oleh subjek.

Mayoritas orangtua dan guru di sekolah tidak mengetahui perilaku perundungan yang dilakukan subjek di sekolah. Orang tua dan guru subjek juga tidak memberikan intervensi mengenai perilaku perundungan kepada subjek. Tiga dari dua subjek melakukan perilaku perundungan untuk meningkatkan harga diri. Subjek juga memiliki lingkungan pertemanan yang biasanya melakukan perilaku perundungan.

\section{Saran untuk Penelitian Selanjutnya}

Peneliti menyarankan peneliti berikutnya untuk memilih satu atau dua faktor perilaku perundungan agar dapat menggali informasi lebih dalam. Semakin banyak faktor yang digunakan, maka peneliti membutuhkan waktu yang lebih panjang untuk wawancara. Sedangkan 
subjek memiliki keterbatasan waktu untuk diwawancara.

\section{Saran untuk Pelaku Perundungan}

Pertama, subjek dapat memperluas pergaulannya dengan cara berbaur dengan orang-orang yang memiliki karakter yang lebih beragam, sehingga dapat mempertimbangkan perilaku yang baik untuk ditiru dan perilaku yang tidak baik untuk ditiru.

Kedua, Subjek tentunya tidak menerima jika ada teman atau siswa/i di sekolah subjek yang memperilakukan subjek secara tidak baik atau merundung subjek. Oleh sebab itu, subjek juga diharapkan berhenti melakukan perilaku perundungan terhadap korban perilaku perundungan.

Ketiga, meningkatkan rasa percaya diri atau harga diri tidak hanya dapat dilakukan dengan cara merundung. Subjek dapat mencari kegiatan positif atau mengembangkan kemampuan/talenta dalam diri subjek, sehingga hal tersebut membuat subjek merasa lebih percaya diri atas kemampuan yang subjek miliki.

\section{Saran untuk Orangtua}

Pertama, orangtua bukan hanya memberikan larangan dan teguran, tetapi juga memberikan edukasi mengenai perilaku perundungan beserta dengan dampaknya sedini mungkin. Orangtua perlu lebih peka terhadap dampak perilaku perundungan dengan cara membaca buku mengenai perilaku perundungan.

Kedua, keluarga menghindari kebiasaan memukul dan mencaci anak karena hal tersebut dapat ditiru oleh anak terhadap teman atau saudaranya yang lain.

Ketiga, orangtua lebih aktif dalam berkomunikasi dengan anak setiap harinya untuk mengetahui kegiatan yang dilakukan anak. Namun, orangtua perlu menghindari tuduhan, caci maki, hukuman secara fisik apabila anak didapati melakukan perilaku perundungan. Sebaliknya orangtua dapat memberikan teguran, penjelasan, pengertian dan wawasan kepada anak mengenai alasan anak tidak boleh melakukan perilaku perundungan.

\section{Saran untuk Pendidik Profesional}

Pertama, pendidik Profesional dapat memberikan edukasi dan penyuluhan mengenai perilaku perundungan, bukan hanya memberikan peraturan mengenai perilaku perundungan. Peraturan yang diberikan tanpa edukasi malah membuat siswa/i melakukan perilaku perundungan disaat tidak ada pengawasan pendidik profesional. Sebaiknya, pendidik profesional tidak mencemooh siswa/i lain meskipun dalam konteks bergurau karena hal tersebut dapat ditiru oleh siswa/i lain dengan tujuan menghina temannya.

Kedua, pendidik profesional dapat memberikan kegiatan kepada siswa/i seperti simulasi atau role play dengan tema perundungan, camping atau retreat yang dapat mempererat hubungan antar siswa. Namun, pendidik perlu memantau siswa/i secara intensif untuk menghindari kemungkinan terjadinya perilaku perundungan yang dilakukan oleh siswa/i.

Ketiga, pendidik profesional lebih memerhatikan perilaku siswa/i di sekolah dengan cara meningkatkan komunikasi dengan siswa/i, memantau perilaku siswa/i di sekolah saat istirahat sedang berlangsung dan lebih aktif dalam mencari tahu aktivitas/kegiatan yang biasanya dilakukan siswa/i di sekolah, sehingga dapat menambah informasi mengenai perilaku yang biasannya dilakukan oleh siswa/i di sekolah.

\section{DAFTAR PUSTAKA}

Arikunto, S. (2010). Prosedur penelitian suatu pendekatan praktik. Jakarta: Rineka Cipta.

Collin, C. (2012). The psychology book. New York: DK Publishing.

Fischer. (2013). Bullies, victims and bullyvictims impact on health profile. Sociedade \& Culturas, 38, 53-75.

Fitria \& Auli, R. (2016). Faktor-faktor yang berhubungan dengan perilaku bullying. Idea Nursing Journal, 7(3), 9-17.

Gulo. (2010). Metodologi penelitian. Jakarta: Grasindo. 
Jackson, A.Y. (2012). Thinking with theory in qualitative research. New York: British Library Cataloguing.

Junita. (2017). Kondisi emosi pelaku bullying (studi kasus pada siswa kelas VIII di SMP DIPONEGORO 1 Jakarta). Jurnal UNJ, 57-63.

Kustanti, E. R. (2017). Kelekatan, harga diri dan penyesuaian pada korban perundungan. Jurnal Psikologi, 16(2), 113-121.

Lestari, W. S. (2016). Analisis faktor-faktor penyebab bullying di kalangan peserta didik. SOCIO DIDAKTIKA: Social Science Education Journal, 3(2), 147-157.

Letendre, J. (2016). Teacher and staff voices: Implementation of a positive behavior bullying prevention program in an urban school. Children \& Schools, 38(4), 235-243.

Moleong, L.J. (2010). Metodologi penelitian kualitatif. Bandung: Remaja Rosdakarya.

Mufrihah, A. (2016). Perundungan reaktif di sekolah dasar dan intervensi berbasis nuansa sekolah. Jurnal Psikologi, 43(2), 135-153.

O'Connell, J. (2003). Bullying at school. California: Department of Education.

Papalia, D.E. \& Feldman, R.D. (2012). Experience human development. New York: McGraw-Hill.

Poerwandari, E.K. (2011). Pendekatan kualitatif untuk penelitian perilaku manusia. Indonesia: LPSP3 UI.

Prastiya, E.C. (2015). Penerimaan diri siswa sekolah menengah pertama Bukit Sion Jakarta Barat. Jurnal Psiko-Edukasi, 16, 35-47.

Rahmawati. (2016). Pengaruh penggunaan teknik menggambar untuk mengurangi kecemasan sosial terhadap korban cyberbullying (studi kuasi eksperimen terhadap siswa kelas VIII di SMP Negeri 259 Jakarta Timur). Jurnal Bimbingan Konseling, 5(1), 20-26.

Rahmawati, S.W. (2016). Peran iklim sekolah terhadap perundungan. Jurnal Psikologi, 43(2), 167-180.

Santrock, J.W. (2007). Adolescence (11 ${ }^{\text {th }}$ ed.). The McGraw-Hill.
Sari, R.N. \& Agung, I.M. (2015). Pemaafan dan kecenderungan perilaku bullying pada siswa korban bullying. Jurnal Psikologi, 11(1), 32-36.

Sarwono, S.W. (2013). Psikologi remaja. Jakarta: Rajawali Pers.

Schaffer, H.R. (2012). Key concepts in developmental psychology. London: SAGE Publications.

Swearer, S.M. \& Hymel, S. (2015). Understanding the psychology of bullying moving toward a socialecological diathesis-stress model. American Psychologist Association, 70(4), 344-353.

Usman, I. (2013). Kepribadian, komunikasi, kelompok teman sebaya, iklim sekolah dan perilaku bullying. Humanitas, 10(1), 49-60. 